\title{
Determination of $\mathrm{N}$-Linked Sialyl-Sugar Chains in the Lungs of Domestic Cats and Dogs in Thailand Susceptible to the Highly Pathogenic Avian Influenza Virus (H5N1)
}

\author{
Sukanya Thongratsakul ${ }^{1,2,3}$, Thaweesak Songserm ${ }^{3}$, Chaithep Poolkhet ${ }^{3}$, Sachiko Kondo ${ }^{4,5}$, Hirokazu \\ Yagi $^{5}$, Hiroaki Hiramatsu ${ }^{6}$, Masato Tashiro ${ }^{7}$, Harue Okada ${ }^{7}$, Koichi Kato ${ }^{4,5,8,9}$ and Yasuo Suzuki* ${ }^{* 6,10}$ \\ ${ }^{\text {I} C e n t e r ~ f o r ~ A g r i c u l t u r a l ~ B i o t e c h n o l o g y, ~ K a s e t s a r t ~ U n i v e r s i t y, ~ K a m p h a e n g ~ S a e n ~ C a m p u s, ~ N a k h o n ~ P a t h o m, ~ 73140, ~}$ \\ Thailand \\ ${ }^{2}$ Center for Agricultural Biotechnology (AG-BIO/PERDO-CHE), Thailand \\ ${ }^{3}$ Faculty of Veterinary Medicine, Kasetsart University, Nakhon Pathom, 73140, Thailand \\ ${ }^{4}$ GLYENCE Co., Ltd., Aichi, 464-0858, Japan \\ ${ }^{5}$ Graduate School of Pharmaceutical Sciences, Nagoya City University, Aichi, 467-8603, Japan \\ ${ }^{6}$ Department of Biomedical Sciences, College of Life and Health Sciences, and Health Science Hills, Chubu University, \\ Aichi, 487-8501, Japan \\ ${ }^{7}$ Department of Viral Diseases and Vaccine Control, National Institute of Infectious Diseases, Tokyo, 162-8640, Japan \\ ${ }^{8}$ Institute for Molecular Science and Okazaki Institute for Integrative Bioscience, National Institutes of National Science, \\ Aichi, 444-8787, Japan \\ ${ }^{9}$ The Glycoscience Institute, Ochanomizu University, Tokyo, 112-8610, Japan \\ ${ }^{10}$ Global COE Program for Innovation in Human Sciences, University of Shizuoka School of Pharmaceutical Sciences, \\ Shizuoka, 422-8526, Japan
}

\begin{abstract}
Highly pathogenic and potentially pandemic H5N1 avian influenza A viruses have become endemic and are now residing in Asia, Europe, Africa, and the Middle East. H5N1 viruses have been shown to cross the species barrier and infect both dogs and cats. Domestic cats and dogs in Thailand, which were naturally infected with H5N1, exhibited severe pulmonary edema and peumonia in lung tissue as well as in other tissue dysfunctions. In order to understand the structure and quantity of influenza A receptor sialyl sugar chains in cats and dogs, especially in lung tissue, glycosylation profiles of $N$-glycans were determined from lung tissues of dogs and cats susceptible to H5N1 in Thailand by using multidimensional HPLC mapping combined with mass spectrometry. The results demonstrated different $N$-linked glycans composition ratios between dogs and cats. There were a total of 30 kinds of $N$-linked glycans from cat lungs, which were comprised of 11 neutral, 13 mono-, 3 di-, and 3 tri-sialyl sugar chains, and 29 kinds from dog lungs, which were comprised of 16 neutral, 11 mono- and 2 di-sialyl sugar chains. Cat lungs exhibited both 5- $\mathrm{N}$-acetylneuraminic acid and 5-Nglycolylneuraminic acid sialic acid (Sia 2-3Gal and Siaa2-6Gal), but dog lungs contained only 5- $N$-acetylneuraminic (Sia 2 2-3Gal and Sia 2-6Gal) molecular species. The composition ratios of molar percentage of Siaa2-3Gal for domestic cat and dog lungs were 21.5 and 9.9, respectively, while the composition ratios of Siaa2-6Gal were 47.1 and 59.2, respectively. These results may indicate that domestic cats are more susceptible than dogs to H5N1 influenza virus infection and also cats and dogs play an important role as "mixing vessels" for the virus re-assortment.
\end{abstract}

Keywords: Cat, Dog, H5N1, Lung, Sialyl sugar chains, Influenza virus.

\section{INTRODUCTION}

Highly pathogenic avian influenza (HPAI) is one of the most widely distributed zoonotic infectious diseases in the world, and furthermore, the pathogenic influenza virus is extremely prone to mutation. The H5N1 avian influenza

*Address correspondence to this author at the Department of Biomedical Sciences, College of Life and Health Sciences, and Health Science Hills, Chubu University, 1200 Matsumoto-cho, Kasugai-shi, Aichi, 487-8501, Japan; Tel/Fax: +81 56851 6391; E-mail: suzukiy@isc.chubu.ac.jp virus is a highly contagious and deadly pathogen in poultry, which has been transmitted to humans, and has potentially generated mutations during human-to-human propagation $[1,2]$. Fatal avian H5N1 viruses have been demonstrated to cross the species barrier, and infect humans as well as felines, including domestic cats [3-5], leopards, and tigers $[6,7]$. The H5N1 viruses have also been isolated from domestic dogs [8,9]. Furthermore, influenza viruses can be isolated from many species, such as humans, pigs, horses, mink, mice, ferrets, cynomolgus macaques, cats, leopards, tigers, marine mammals, and a wide range of domestic birds 
$[5,10,11]$. Previous experimental studies have revealed viral antigens in lung tissue after intratracheal inoculation with H5N1 virus in 4 to 6 month-old European shorthair cats [3]. Moreover, necropsy of domestic cats and dogs in Thailand found incidences of nasal discharge, severe pulmonary congestion, and pulmonary edema, since the viruses are predominantly attached to the lower respiratory tract, indicating that the important organ of viral infection is the lung $[4,12]$.

With regard to human cases, HPAI H5N1 was first reported in poultry farms and wet markets located in Hong Kong in 1997 [10,13]. The clinical signs of this disease resulted in severe respiratory tract distress and multiple organ dysfunctions, which require hospitalization. Additionally, the autopsy results from a patient that died after the onset of H5N1 infection in Thailand revealed the proliferative phase of diffused alveolar macrophage, interstitial pneumonia, focal hemorrhage, and bronchitis. These results also suggest that virus replication is predominantly in lung tissue [14]. Influenza A virus binding involves interaction between a receptor-binding site on hemagglutinin (HA) and the sialyl receptor, which is known as sialic acid [2]. Results of recent studies have indicated that $\mathrm{N}$-linked sialoglycoproteins are required for influenza virus infection and entry into host cells of influenza viruses, at least for influenza A (H1N1 and H3N2) and influenza B viruses $[15,16]$. The hemagglutinin of the virus recognizes different linkages, dependent on the viral particle encountering avian or mammal hemagglutinin strains. Hemagglutinin of human and avian influenza A isolates recognizes sialic acid with $\alpha 2-6$ and $\alpha 2-3$ linkages, respectively, and HA of type B viruses prefers the 02 -6-linked sialic acid [17,18]. Avian strains preferentially bind to $\alpha 2-3$ linkage (Neu5Aca2-3Gal), while human strains have specificity for $\alpha 2-6$ linkages (Neu5Aca2-6 Gal) $[2,19,20]$.

Pigs are susceptible to respiratory infections by both avian and human strains, since the pig trachea contains carbohydrates with both $\alpha 2-3$ and $\alpha 2-6$ linked sialic acids $[21,22]$. Some investigations have suggested that pigs might attract influenza pandemics by serving as a "mixing vessel", through which antigenically-novel avian-human re-assortant viruses might be generated following co-infections [21,22]. However, there have been no studies, thus, far identifying the structural formula, molecular weight, or characteristics of $\mathrm{N}$-linked glycans in domestic animals that are in close contact with humans. This investigation characterized $\mathrm{N}$-glycans derived from domestic cats and dogs in Thailand that have been reported to exhibit susceptibility to highly pathogenic avian influenza A viruses [4,12], through utilization of the high-performance liquid chromatography (HPLC) mapping method, which is applicable for determining $N$-glycan profiles in a quantitative manner at molecular, cellular, and tissue levels [23].

\section{MATERIALS AND METHODOLOGY}

\section{Tissue Preparation from Cat and Dog Lung Tissue}

To study the structure of $N$-linked glycans in the lower respiratory tract of cats and dogs, particularly in the lungs, lung tissue were directly collected from donated animals at the Kasetsart University Veterinary Teaching Hospital (KUVTH), Faculty of Veterinary Medicine, Kasetsart University, Thailand. These animals died without respiratory tract infections, and samples were collected from a total of three dogs and three cats ranging from 2 months to 8 years old.

Freshly harvested lungs were individually weighed and placed in a homogenization tube with miliQ water using sterile technique. The homogenates poured into freeze-drying bottles to lyophilize the lung tissue. Total dry weight tissue of cats and dogs were 1.36 and 2.49 grams, respectively, and $100 \mathrm{mg}$ of the freeze-dried samples were delipidated using $80 \%$ ethanol, $100 \%$ ethanol, Chloroform/Methanol (2:1, $\mathrm{v} / \mathrm{v})$, and Chloroform/Methanol/miliQ water $(1: 2: 0.8, \mathrm{v} / \mathrm{v} / \mathrm{v})$ [24]. After lipid removal, the remaining $10 \mathrm{mg}$ was used for the structural analysis of sugar chains as starting materials.

\section{Purification and Characterization of $N$-Linked Glycans}

All experimental procedures used, including the enzymatic, chromatographic, and mass spectrometric conditions, have been previously described [25-27]. The lung tissue extractions were proteolyzed with pepsin and further digested with glycoaminidase A to release $\mathrm{N}$-glycans. The reducing ends of the released glycans were labeled with fluorescent reagent 2 -aminopyridine, under previously described conditions [28]. These pyrimidylamino (PA)-glycans were fractionated on a diethylaminoethyl (DEAE) column $(7.5 \times 75$ $\mathrm{mm}$, Tosoh, Tokyo, Japan), according to sialic acid contents. Each fraction was separated by an octadecyl silica (ODS) column $(6 \times 150 \mathrm{~mm}$, Shimadzu, Kyoto), and the recorded elution time represents the glucose unit (GU) value. The individual fractions were subjected to matrix-assisted laser desorption/ionization-time of flight mass spectrometry (MALDI-TOF-MS). Fractions, including some $\mathrm{N}$-glycans, were further separated by an amide column $(4.6 \times 250 \mathrm{~mm}$, Tosoh) and GU values recorded. The identification of $N$ glycan structures was based on GU and mass values in comparison to PA-glycans in the GALAXY database (http://www.glycoanalysis.info/galaxy2/ENG/systemin1.jsp) [29]. The structures of PA-glycans not previously registered in GALAXY were characterized by exoglycosidase treatments $\quad(\alpha$-sialidase, $\alpha 2,3$-sialidase, $\alpha$-fucosidase, $\alpha$ galactosidase, $\beta$-galactosidase, and $\beta$ - $N$-acetylglucosaminidase) and mass spectrometric analysis, as previously described $[25,27]$.

\section{RESULTS AND DISCUSSION}

\section{Isolation of Neutral Glycans and Acidic Glycans from Domestic Cat and Dog Lung Tissue}

We performed $\mathrm{N}$-glycosylation profiling of domestic dog and cat lung tissues by multi-dimensional HPLC mapping combined with mass spectrometric analysis. The neutral glycans and acidic PA-glycans derived from the lung tissues were separated by a diethylaminoethyl (DEAE) column. There were four peaks of individual $N$-linked glycans, which were comprised of one peak of neutral glycans and three peaks of acidic glycans (mono-sialyl, di-sialyl and tri-sialyl sugar) at 2, 12, 23, and 27 min retention times, respectively (Fig. 1a). The composition ratios of the molar percentages of the neutral, mono-sialyl, di-sialyl, and tri-sialyl forms of $N$ linked glycans from cat lung tissue were 28, 24.6, 41.3, and 6.1 , respectively, and those from dog tissue were $27.9,16.6$, and 55.4, respectively, with dog tissue lacking tri-sialyl $\mathrm{N}$ linked glycans (Table 1). 
(a)

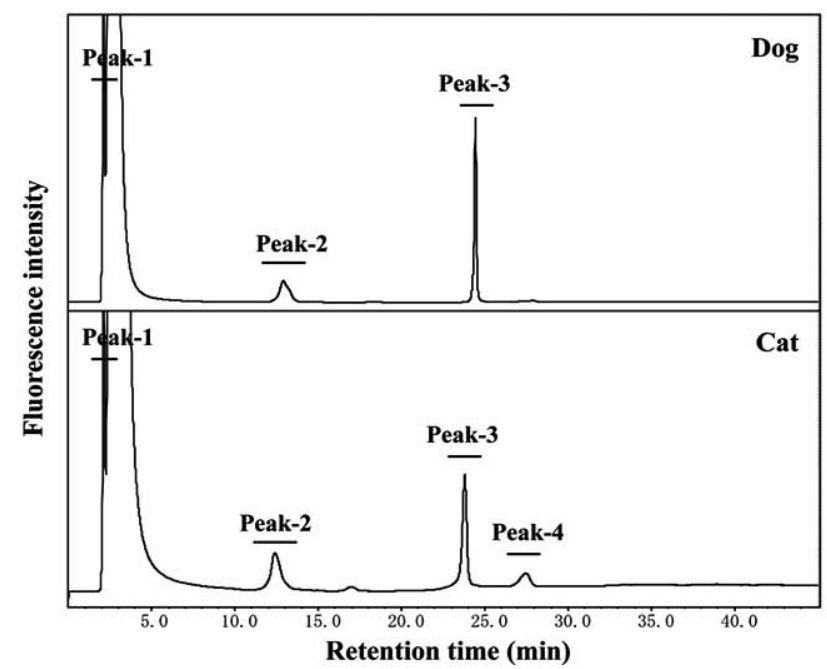

(c)

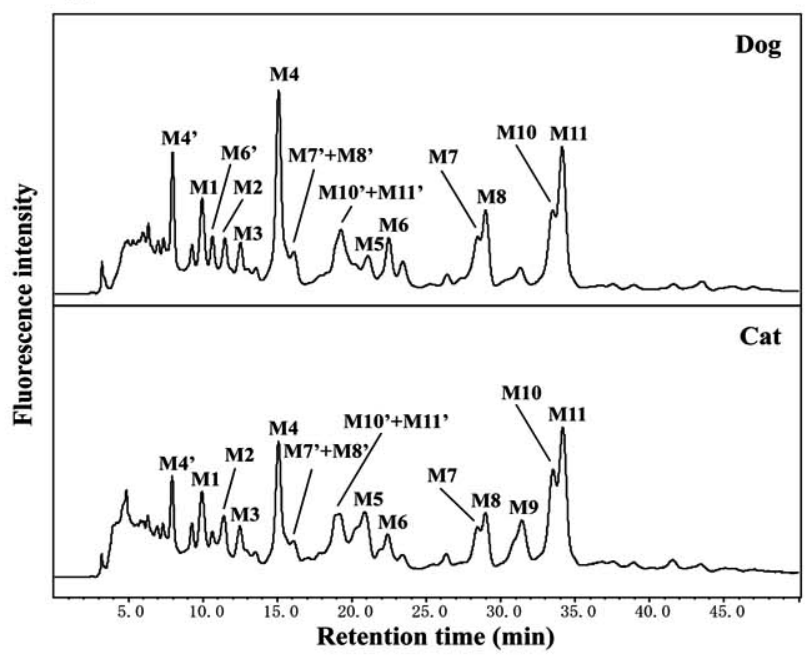

(b)

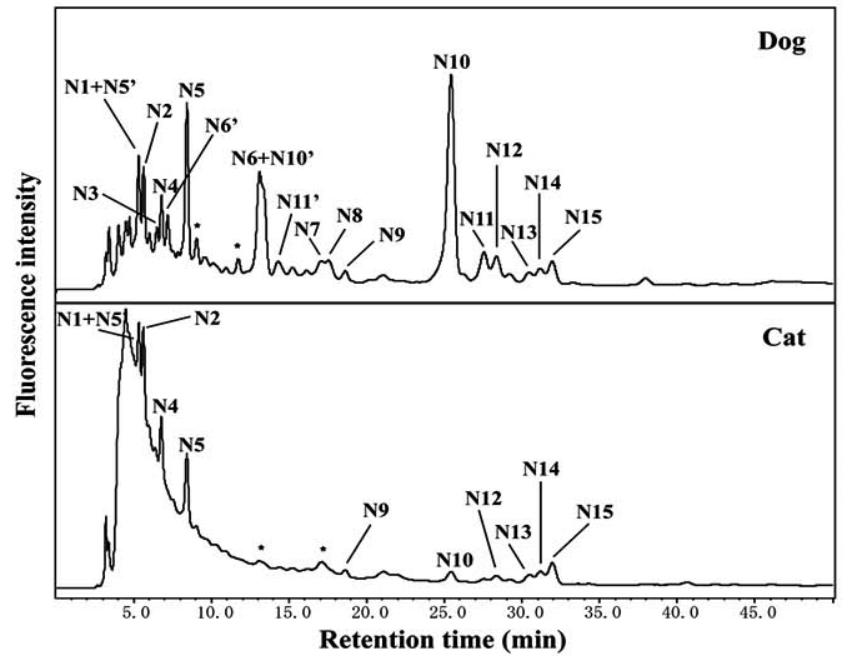

(d)

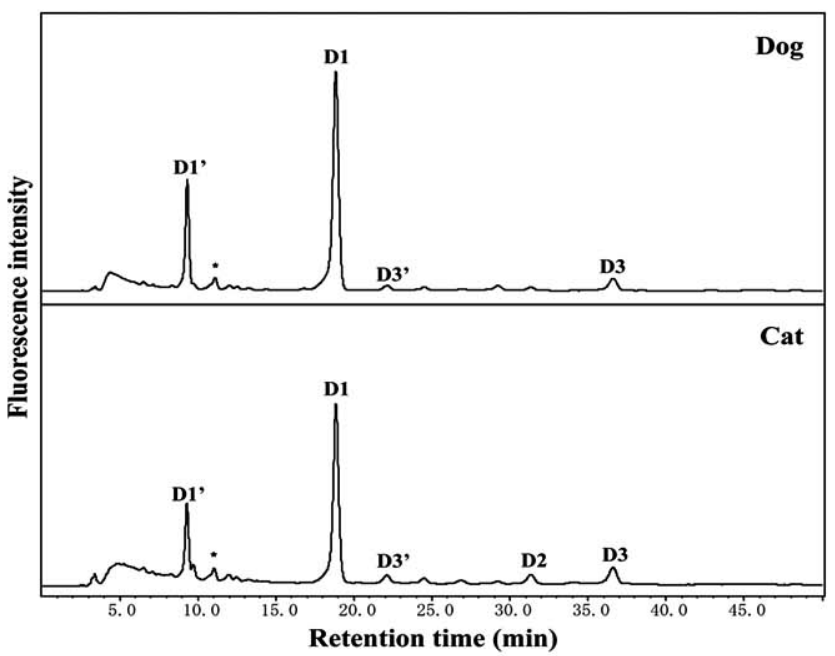

(e)

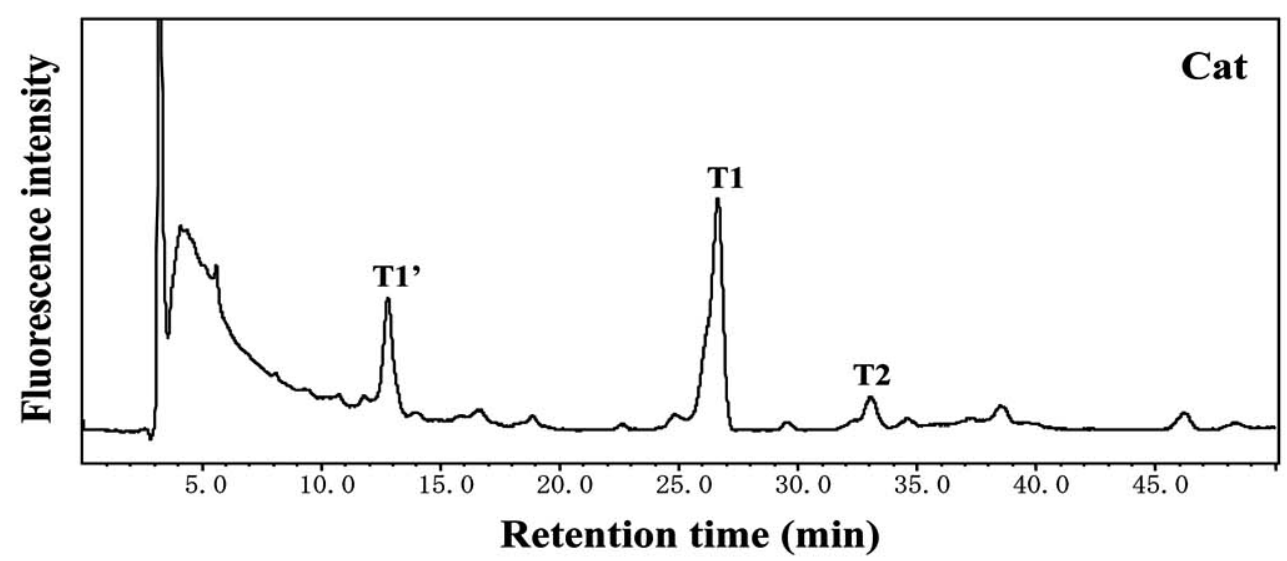

Fig. (1). Comparison of HPLC profiles (a-e) of pyridylamino (PA) derivatives of $N$-glycans derived from dog and cat lung tissues. The PAglycans from dog and cat lung tissues were separated on diethylamino ethyl (DEAE) column (a). Peaks 1, 2, 3, and 4 indicate the fractions that are neutral, mono-, di-, and tri-sialyl oligosaccharides, respectively. Each peak of the neutral, mono-, di-, and tri-sialyl oligosaccharide was individually applied to an octadecyl silica (ODS) column and given elution profiles of $\mathbf{b}, \mathbf{c}, \mathbf{d}$, and e, respectively. Asterisks indicate the fractions containing no detectable PA-oligosaccharides. 
Table 1. Characteristics of Composition Ratios of Glycan Content Between cat and Dog Lung Tissues

\begin{tabular}{|c|c|c|c|c|c|c|c|c|}
\hline \multirow[t]{2}{*}{ Species } & \multicolumn{4}{|c|}{ Composition Ratios (Molar \%) ${ }^{\mathrm{a}}$} & \multicolumn{2}{|c|}{$\begin{array}{l}\text { Sialyl Sugar Chain } \\
\quad(\text { Molar \%) }\end{array}$} & \multicolumn{2}{|c|}{$\begin{array}{l}\text { Sialyl Sugar Chain } \\
\quad\left(\mathrm{pmol} \mathrm{mg}^{-1}\right)^{\mathbf{b}}\end{array}$} \\
\hline & $\begin{array}{l}\text { Neutral } \\
\text { Sugar }\end{array}$ & $\begin{array}{l}\text { Mono-sialyl } \\
\text { Sugar }\end{array}$ & $\begin{array}{l}\text { Di-sialyl } \\
\text { Sugar }\end{array}$ & $\begin{array}{l}\text { Tri-sialyl } \\
\text { Sugar }\end{array}$ & Siao2-3Gal & Siao2-6Gal & Siao2-3Gal & Sia 2-6Gal \\
\hline Cat & 28.0 & 24.6 & 41.3 & 6.1 & 21.5 & 47.1 & 20.9 & 45.7 \\
\hline Dog & 27.9 & 16.6 & 55.4 & - & 9.9 & 59.2 & 28.8 & 167.3 \\
\hline
\end{tabular}

${ }^{a}$ The molar percentage of glycan contents in cat and dog lung tissues was calculated on the basis of the peak areas in Fig. (1b-e) by comparison with total glycan content in the lung tissues, respectively.

${ }^{\mathrm{b}}$ Total amount of sialyl sugar chain derived from domestic cat and dog lung tissue dry weight $\left(\mathrm{pmol} \mathrm{mg}^{-1}\right)$.

Each fraction separated by the DEAE column from peaks $1,2,3$, and 4 was individually applied to an ODS column, and the individual sub-fractions were subjected to MALDITOF-MS analysis. There were 16 major peaks of neutral, 13 major peaks of mono-sialyl, 3 major peaks of di-sialyl, and 3 major peaks of tri-sialyl glycans (Fig. 1b-e). The peaks N2, M1, M9, and T1, which included two kinds of $N$-glycans, were further separated utilizing an amide column. The PAoligosaccharides were identified on the basis of HPLC elution time, normalized by GU and mass values, in comparison to PA-glycans in the GALAXY database. For example, the major $N$-glycan that corresponded to peak D1 was eluted at 11.0 GU on the ODS column. The molecular mass of this glycan was $2302 \mathrm{Da}$, as determined by MALDI-TOF-MS analysis. The data set was in good agreement with the known reference for di-sialyl glycan,

Neu 5 Ac $\alpha 2 \rightarrow 6$ Gal $\beta 1 \rightarrow 4$ GlcNAc $\beta 1 \rightarrow 2$ Man $\alpha 1 \rightarrow 6($ Neu 5 $\mathrm{Ac} \alpha 2 \rightarrow 6 \mathrm{Gal} \beta 1 \rightarrow 4 \mathrm{GlcNAc} \beta 1 \rightarrow 2 \mathrm{Man} \alpha 1 \rightarrow 3) \mathrm{Man} \beta 1 \rightarrow 4 \mathrm{Glc}$ $\mathrm{NAc} \beta 1 \rightarrow 4$ GlcNAc-PA (code no. $2 \mathrm{~A} 1-200.4$ in the GALAXY database). The structure of this PA-oligosaccharide was confirmed by co-chromatography. The PA-glycans that corresponded to the fractions N9, N14, N15, M1-2, M2, M3, M5, M8, M9-2, and M11 did not match any of the PAglycans registered in GALAXY. These compounds were trimmed by exoglycosidase treatments to identify known PA-glycans. The original structures of these PA-glycans were uniquely determined by taking into account the specificities of the used exoglycosidases.

In this study, 35 kinds of $\mathrm{N}$-glycans derived from dog and cat lung tissue were identified, which included the epimerization of $\mathrm{N}$-glycans. In total, 30 types of $N$-linked glycans (11 neutral glycan, 13 mono-sialyl, 3 di-sialyl, and 3 trisialyl sugar chains) existed in cat lungs, and 29 types (16 neutral glycan, 11 mono-sialyl, and 2 di-sialyl sugar chains) in dog lungs. Collectively, the ratio of molar percentage of neutral glycans and acidic glycans was approximately 30:70 for both cat and dog tissues. The reference code numbers, structures, and relative quantities (\%) of $N$-linked glycans from dog and cat lung tissues are shown in Table 2.

Cat lungs contained both Neu5Ac and Neu5Gc molecular

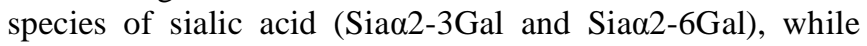

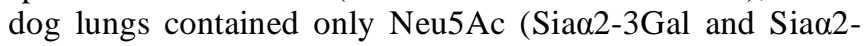
$6 \mathrm{Gal})$. The composition ratios of the molar percentage of

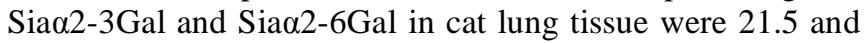
47.1 , respectively, while the composition ratios in dog lung tissue were 9.9 and 59.2, respectively (Table 1). However,

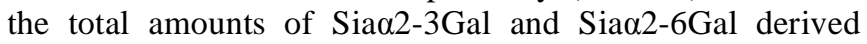

from cat lungs were 20.9 and $45.7 \mathrm{pmol} \mathrm{mg}^{-1}$, respectively, and the total amounts from dog lungs were 28.8 and 167.3 pmol mg ${ }^{-1}$ of tissue dry weight, respectively (Table 1). Interestingly, these results demonstrated that only cat lung tissue possessed $\alpha 2-3$ Neu5Ac and $\alpha 2-3$ Neu5Gc residues of monosialyl PA-glycan, which corresponded to peak M9. Moreover, the Neu5Aca2-3Gal and Neu5Aca2-6Gal in the same glycan of the di-sialyl (peak D2) and tri-sialyl sugar chain (peaks T1, T1', and T2) were also detected only in cat lung tissue (Table 2).

Previous studies demonstrated that the distribution of sialic acid species varies in different animals. For example, pig and horse tissue contain large amounts of Neu5Gca23Gal, while chicken tissue does not have Neu5Gc, and humans are the mammal that lack Neu5Gc expression in normal tissue [30]. More than $90 \%$ of the horse trachea epithelial cells contain Neu5Gc [2], and previous studies indicated that the Neu5Gc $\alpha 2-3 \mathrm{Gal}$ moiety is critical for influenza A replication in horse and duck species [2,31]. Neu5Gc was also found in cat lung tissue, however, the total composition of Neu5Gc was less than Neu5Ac. Moreover, the higher ratio of the Sian2-3Gal and avian-type receptor sialyl-sugar linkage in cat lung tissue $(21.5 \%)$ compared to dog lungs $(9.9 \%$ ) (Table 1) may indicate the reason that cats are more susceptible than dogs to avian influenza infection. Therefore, we suggest that domestic cats and dogs as well as pigs, chickens, and quails, which have already been reported as "mixing vessel" animals for the virus re-assortment, should be part of the alert or there should be special monitoring during $\mathrm{H} 5 \mathrm{~N} 1$ outbreaks.

In addition, $\mathrm{H} 5 \mathrm{~N} 1$ viruses can be found in other organs, such as heart, intestine, placenta, trachea, brain [32,33], cerebrospinal fluid [34], and faeces [32]. Furthermore, H5N1 viruses were also found in fetal mononuclear cells, macrophages in the liver, and the fetal placenta [33]. These results indicate that all of these organs possess avian influenza virus receptors and the virus could be transmitted from mother to fetus by the transplacental route. With respect to these results, further investigations should focus on characterizing the structures of avian influenza virus receptors and demonstrating the vertical transmission in animals.

In summary, domestic cats and dogs in Thailand were demonstrated to have both $N$-linked Sia 2 -3Gal and Sia 2 $6 \mathrm{Gal}$ linkages in lower respiratory tract lung tissue, indicating that cats and dogs might play an important role as "mixing vessels" for the virus re-assortment. The composition

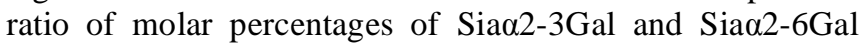


Table 2. Structure of $N$-Glycans Derived from Dog and Cat Lung Tissues, and Prevalence (mol \%)

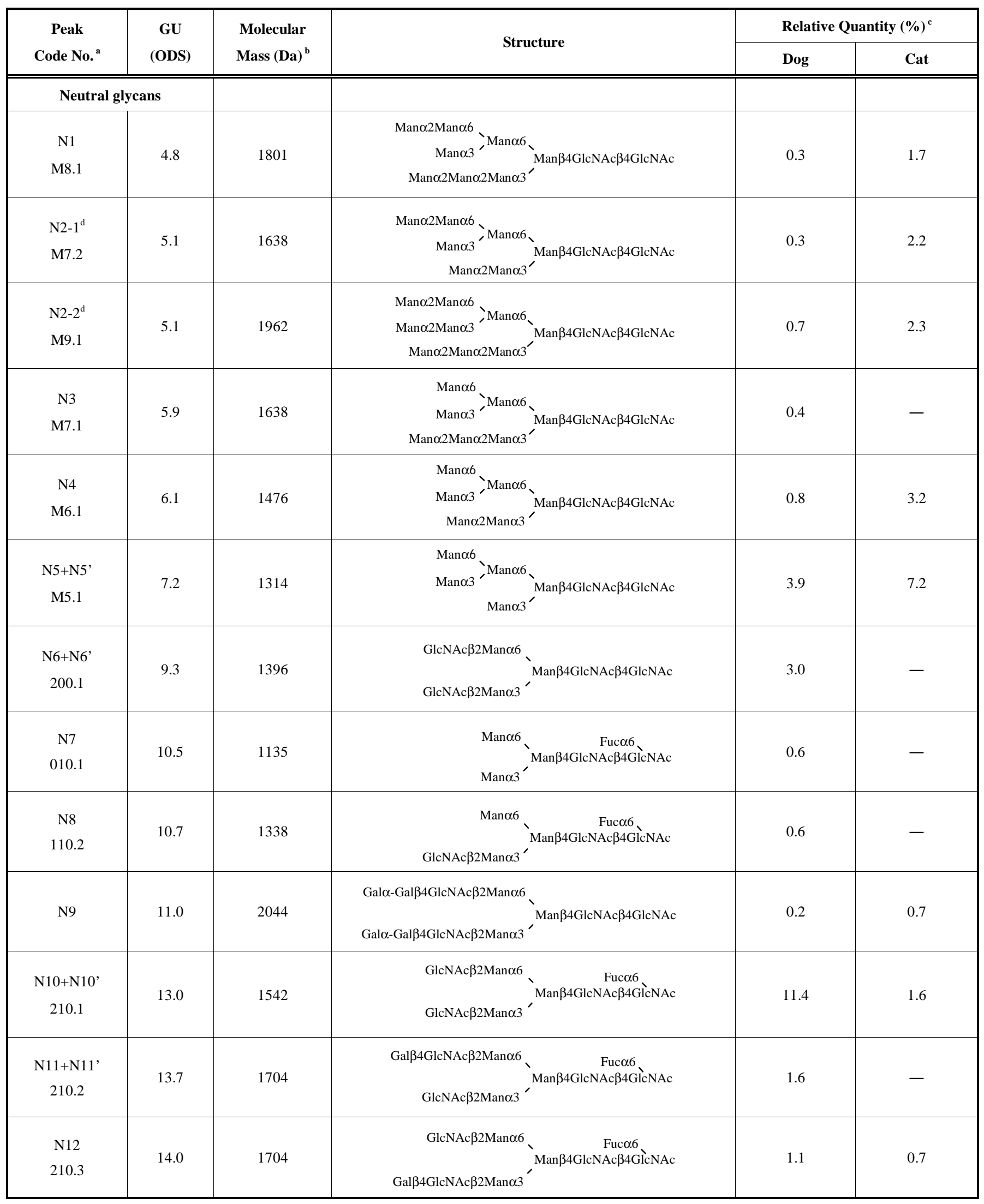


(Table 2). Contd....

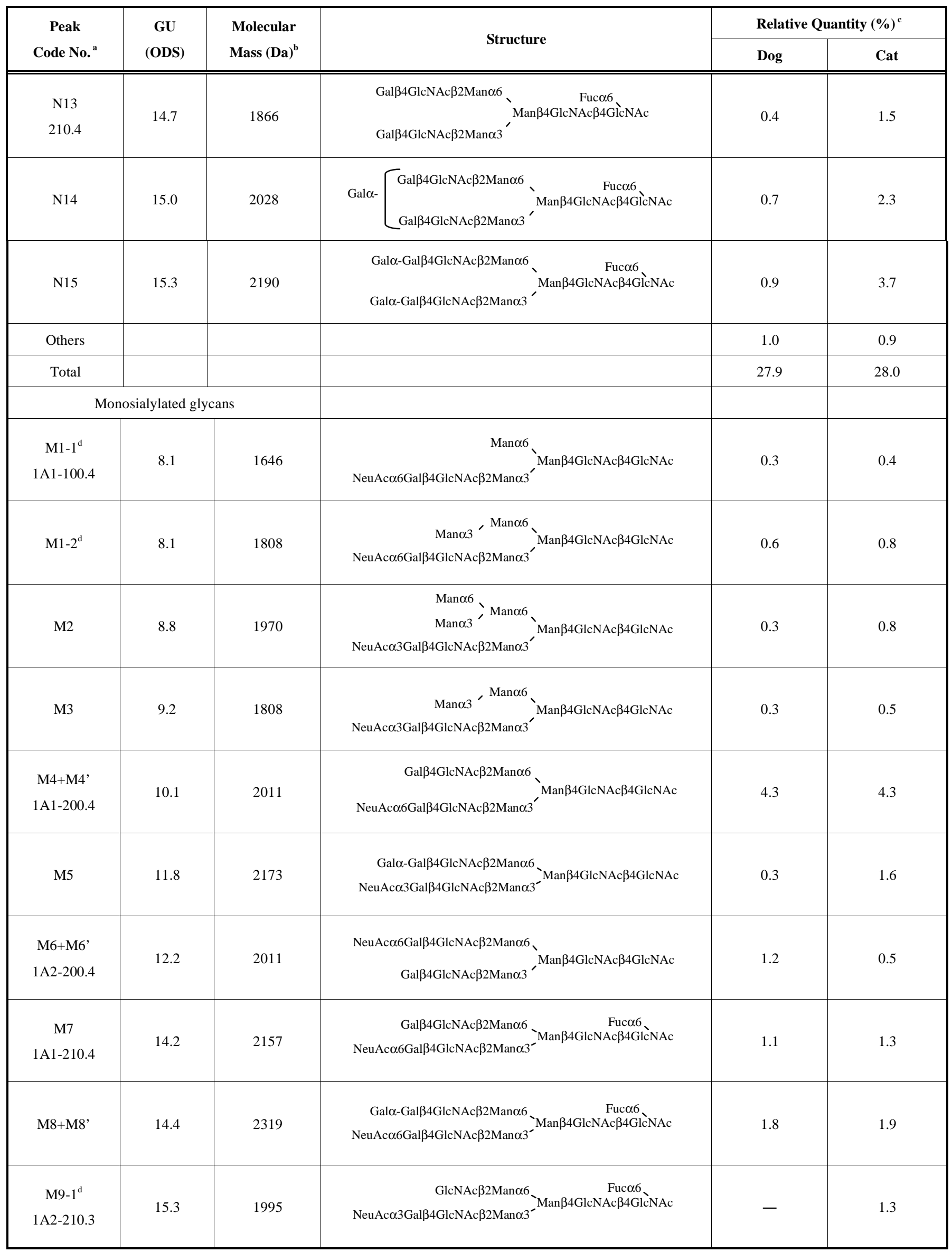


(Table 2). Contd.....

\begin{tabular}{|c|c|c|c|c|c|}
\hline \multirow{2}{*}{$\begin{array}{c}\text { Peak } \\
\text { Code No. }\end{array}$} & \multirow{2}{*}{$\begin{array}{c}\text { GU } \\
(\text { ODS) }\end{array}$} & \multirow{2}{*}{$\begin{array}{l}\text { Molecular } \\
\text { Mass (Da) }\end{array}$} & \multirow{2}{*}{ Structure } & \multicolumn{2}{|c|}{ Relative Quantity (\%) } \\
\hline & & & & Dog & Cat \\
\hline M9-2 ${ }^{\mathrm{d}}$ & 15.3 & 2335 & $\begin{array}{c}\text { Gal } \alpha-G a l \beta 4 G l c N A c \beta 2 M a n \alpha 6 \\
\text { NeuGc } \alpha 3 \text { Gal } \beta 4 G l c N A c \beta 2 M a n \alpha 3^{-}\end{array}$ & - & 0.7 \\
\hline $\begin{array}{l}\mathrm{M} 10+\mathrm{M} 10 \\
1 \mathrm{~A} 3-210.4\end{array}$ & 16.1 & 2157 & $\begin{array}{c}\text { Gal } \beta 4 G l c N A c \beta 2 M a n \alpha 6 \\
\text { NeuAc } \alpha 3 \text { Gal } \beta 4 G l c N A c \beta 2 M a n \alpha 3\end{array}$-Man $\beta 4$ GlcNAc $\beta 4$ Glc̀NAc & 1.9 & 3.8 \\
\hline M11+M11' & 16.4 & 2319 & 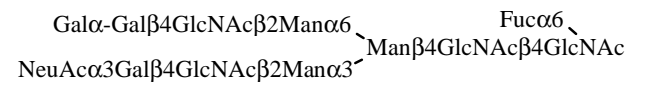 & 3.6 & 5.7 \\
\hline Others & & & & 0.9 & 1.0 \\
\hline Total & & & & 16.6 & 24.6 \\
\hline \multicolumn{6}{|c|}{ Disialylated glycans } \\
\hline $\begin{array}{c}\mathrm{D} 1+\mathrm{D} 1 \\
2 \mathrm{~A} 1-200.4\end{array}$ & 11.0 & 2302 & $\begin{array}{l}\text { NeuAc } \alpha 6 \text { Gal } \beta 4 \text { GlcNAc } \beta 2 \text { Man } \alpha 6 \text { 、' Man } \beta 4 \text { GlcNAc } \beta 4 \text { GlcNAc } \\
\text { NeuAc } \alpha 6 \text { Gal } \beta 4 \text { GlcNAc } \beta 2 M a n \alpha 3^{\prime}\end{array}$ & 49.9 & 33.6 \\
\hline $\begin{array}{c}\mathrm{D} 2 \\
2 \mathrm{~A} 3-210.4\end{array}$ & 15.0 & 2448 & $\begin{array}{l}\text { NeuAc } \alpha 3 \mathrm{Gal} \beta 4 \mathrm{GlcNAc} \beta 2 \mathrm{Man} \alpha 6 \\
\text { NeuAc } \alpha 6 \mathrm{Gal} \beta 4 \mathrm{GlcNAc} \beta 2 \mathrm{Man} \alpha 3^{\prime}\end{array}$ & 一 & 1.6 \\
\hline $\begin{array}{c}\mathrm{D} 3+\mathrm{D} 3 \\
2 \mathrm{~A} 4-210.4\end{array}$ & 17.0 & 2448 & $\begin{array}{l}\text { NeuAc } \alpha 3 \text { Gal } \beta 4 G l c N A c \beta 2 M a n \alpha 6 \\
\text { NeuAc } \alpha 3 \text { Gal } \beta 4 G l c N A c \beta 2 M a n \alpha 3^{\prime}\end{array}$ & 3.5 & 4.2 \\
\hline Others & & & & 2.1 & 1.9 \\
\hline Total & & & & 55.4 & 41.3 \\
\hline \multicolumn{6}{|c|}{ Trisialylated glycans } \\
\hline $\begin{array}{l}\mathrm{T} 1-1+\mathrm{T} 1-1^{, \mathrm{d}} \\
3 \mathrm{~A} 3-300.8\end{array}$ & 13.4 & 2958 & $\begin{array}{l}\text { Neu5Ac } \alpha 3 \text { Gal } \beta 4 \text { GlcNAc } \beta 2 \text { Man } \alpha 6 \\
\text { Neu5Ac } \alpha 3 \text { Gal } \beta 4 \text { GlcNAc } \beta 4 \text { 、'Man } \alpha 3 \text {-Man } \beta 4 \text { GlcNAc } \beta 4 \text { GlcNAc } \\
\text { Neu5Ac } \alpha 6 \text { Gal } \beta 4 \text { GlcNAc } \beta 22^{\prime}\end{array}$ & - & 1.0 \\
\hline $\begin{array}{l}\mathrm{T} 1-2+\mathrm{T} 1-2, \mathrm{~d} \\
3 \mathrm{~A} 2-300.8\end{array}$ & 13.4 & 2958 & $\begin{array}{l}\text { Neu5Ac } \alpha 6 \mathrm{Gal} \beta 4 \mathrm{GlcNAc} \beta 2 \mathrm{Man} \alpha 6 \\
\text { Neu5Ac } \alpha 3 \mathrm{Gal} \beta 4 \mathrm{GlcNAc} \beta 4 \text { 、'Man } \alpha 3 \\
\text { Neu5Ac } \alpha 6 \mathrm{Gal} \beta 4 \mathrm{GlcNAc} \beta 2\end{array}$ & 一 & 4.2 \\
\hline $\begin{array}{c}\mathrm{T} 2 \\
3 \mathrm{~A} 1-300.8\end{array}$ & 15.7 & 2958 & $\begin{array}{l}\text { Neu5Ac } \alpha 6 \mathrm{Gal} \beta 4 \mathrm{GlcNAc} \beta 2 \mathrm{Man} \alpha 6 \\
\text { Neu5Ac } \alpha 6 \mathrm{Gal} \beta 4 \mathrm{GlcNAc} \beta 4 \text { 、'Man } \alpha 33^{-M a n} \beta 4 \mathrm{GlcNAc} \beta 4 \mathrm{GlcNAc} \\
\text { Neu5Ac } \alpha 6 \mathrm{Gal} \beta 4 \mathrm{GlcNAc} \beta 2^{\prime}\end{array}$ & - & 0.4 \\
\hline Others & & & & 一 & 0.5 \\
\hline Total & & & & - & 6.1 \\
\hline
\end{tabular}

${ }^{a}$ PA-oligosaccharides are coded according to the literature (Takahashi \& Kato, 2003).

${ }^{\mathrm{b}}$ Average mass calculated from the $\mathrm{m} / \mathrm{z}$ values of $[\mathrm{M}+\mathrm{Na}]^{+}$and $[\mathrm{M}-\mathrm{H}]^{-}$ions for neutral and sialyl oligosaccharides, respectively.

${ }^{c}$ Molar percentages of glycan content in dog and cat lung tissues were calculated on the basis of peak areas in Fig. (1b-e) by comparison with total glycan content in the dog and cat lung tissues, respectively.

${ }^{\mathrm{d}}$ Fractions N2, M1, M9, and T1 from the ODS column was separated into two sub-fractions on the amide column. The molar percentage of each glycan was calculated on the basis of peak areas in the elution profile on the amide column. 
was 21.5:47.1 in domestic cat and 9.9:59.2 in dog lung tissue. Neu5Gc and tri-sialyl sugar chains were found in domestic cat, but not in domestic dog lung tissue. These results indicate that domestic cats are more susceptible than dogs to H5N1 influenza virus infection. The structure of receptor sialyl sugar chains in different host species may be useful for the development of new anti-influenza drugs and to clarify the mechanism or pathogenesis of H5N1 infection and viral tropism in other mammals.

\section{ABBREVIATIONS}

\begin{tabular}{|c|c|c|}
\hline $\mathrm{Da}$ & $=$ & dalton \\
\hline DEAE & $=$ & diethylaminoethyl \\
\hline Gal & $=$ & galactose \\
\hline GALAXY & $=$ & $\begin{array}{l}\text { Glycoanalysis by the three axes of } \\
\text { mass spectrometry and chromatog- } \\
\text { raphy }\end{array}$ \\
\hline GlcNAc & $=$ & $N$-acetylglucosamine \\
\hline GU & $=$ & $\begin{array}{l}\text { glucose unit value on the ODS and } \\
\text { amide column }\end{array}$ \\
\hline HPLC & $=$ & $\begin{array}{l}\text { high-performance liquid } \\
\text { chromatography }\end{array}$ \\
\hline HPAI & $=$ & highly pathogenic avian influenza \\
\hline MALDI-TOF-MS & & $\begin{array}{l}\text { matrix-assisted laser desorp- } \\
\text { tion/ionization-time of flight-mass } \\
\text { spectrometry }\end{array}$ \\
\hline Neu5Ac & $=$ & 5-N-acetylneuraminic acid \\
\hline Neu5Gc & $=$ & $5-N$-glycolylneuraminic acid \\
\hline ODS & $=$ & octadecyl silica \\
\hline PA & $=$ & pyrimidylamino \\
\hline Sia & $=$ & sialic acid \\
\hline
\end{tabular}

\section{ACKNOWLEDGEMENTS}

This work was supported by the Health and Labor Science Research Grants from the Ministry of Health, Labor, and Welfare, Japan, a grant-in-aid (20390028) from the Ministry of Education, Culture, Sports, Science and Technology, Japan, and by the Center for Agricultural Biotechnology, Postgraduate Education and Research Development Office, Commission on Higher Education, Ministry of Education, and the Faculty of Veterinary Medicine, Kasetsart University, Thailand. A part of this work was also supported by Mitsubishi Foundation, Heiwa Nakajima Foundation, Tokyo Biochemical Research Foundation, Toukai Foundation for Technology, and Daiko foundation, Japan. H.Y. is a recipient of a Japan Society for the Promotion of Science Research Fellowship for Young Scientists, and S.T. is a recipient of Graduate Study and Research in Agricultural Biotechnology supported by the Commission on Higher Education Development project, the Thai Ministry of Education.

\section{REFERENCES}

[1] Webster RG, Peiris M, Chen H, Guan Y. H5N1 outbreaks and enzootic influenza. Emerg Infect Dis 2006; 12: 3-8.

[2] Suzuki Y. Sialobiology of influenza: molecular mechanism of host range variation of influenza viruses. Biol Pharm Bull 2005; 28: 399-408.

[3] Kuiken T, Rimmelzwaan G, van Riel D, et al. Avian H5N1 influenza in cats. Science 2004; 306: 241.
[4] Songserm T, Amonsin A, Jam-on R, et al. Avian influenza H5N1 in naturally infected domestic cat. Emerg Infect Dis 2006; 12: 6813.

[5] van Riel D, Munster VJ, de Wit E, et al. Human and avian influenza viruses target different cells in the lower respiratory tract of humans and other mammals. Am J Pathol 2007; 171: 1215-23.

[6] Amonsin A, Payungporn S, Theamboonlers A, et al. Genetic characterization of $\mathrm{H} 5 \mathrm{~N} 1$ influenza A viruses isolated from zoo tigers in Thailand. Virology 2006; 344: 480-91.

[7] Keawcharoen J, Oraveerakul K, Kuiken T, et al. Avian influenza H5N1 in tigers and leopards. Emerg Infect Dis 2004; 10: 2189-91.

[8] Maas R, Tacken M, Ruuls L, Koch G, van Rooij E, StockhofeZurwieden N. Avian influenza (H5N1) susceptibility and receptors in dogs. Emerg Infect Dis 2007; 13: 1219-21.

[9] Amonsin A, Songserm T, Chutinimitkul S, et al. Genetic analysis of influenza A virus (H5N1) derived from domestic cat and dog in Thailand. Arch Virol 2007; 152: 1925-33.

[10] Rimmelzwaan GF, van Riel D, Baars M, et al. Influenza A virus (H5N1) infection in cats causes systemic disease with potential novel routes of virus spread within and between hosts. Am J Pathol 2006; 168: 176-83.

[11] Sandrock C, Kelly T. Clinical review: update of avian influenza A infections in humans. Crit Care 2007; 11: 209.

[12] Songserm T, Amonsin A, Jam-on R, et al. Fatal avian influenza A H5N1 in a dog. Emerg Infect Dis 2006; 12: 1744-7.

[13] Shortridge KF, Zhou NN, GuanY, et al. Characterization of avian H5N1 influenza viruses from poultry in Hong Kong. Virology 1998; 252: 331-42.

[14] Uiprasertkul M, Puthavathana P, Sangsiriwut K, et al. Influenza A H5N1 replication sites in humans. Emerg Infect Dis 2005; 11: 1036-41.

[15] Chu VC, Whittaker GR. Influenza virus entry and infection require host cell N-linked glycoprotein. Proc Natl Acad Sci USA 2004; 101: 8153-8.

[16] Guo CT, Takahashi N, Yagi H, et al. The quail and chicken intestine have sialyl-galactose sugar chains responsible for the binding of influenza A viruses to human type receptors. Glycobiology 2007; 17: 713-24.

[17] Gagneux P, Cheriyan M, Hurtado-Ziola N, et al. Human-specific regulation of alpha 2-6-linked sialic acids. J Biol Chem 2003; 278: 48245-50.

[18] Olofsson S, Bergstrom T. Glycoconjugate glycans as viral receptors. Ann Med 2005; 37: 154-72.

[19] de Wit E, Fouchier RA. Emerging influenza. J Clin Virol 2008; 41: $1-6$.

[20] Korteweg C, Gu J. Pathology, molecular biology, and pathogenesis of avian influenza A (H5N1) infection in humans. Am J Pathol 2008; 172: 1155-70.

[21] Cross KJ, Burleigh LM, Steinhauer DA. Mechanisms of cell entry by influenza virus. Expert Rev Mol Med 2001; 3: 1-18.

[22] Ito T, Couceiro JN, Kelm S, et al. Molecular basis for the generation in pigs of influenza A viruses with pandemic potential. J Virol 1998; 72: 7367-73.

[23] Takahashi N, Yagi H, Kato K. The two/ three dimensional HPLC mapping method for the identification of $\mathrm{N}$-glycan structures. Compr Glycosci 2007; 2: 283-302.

[24] Terada M, Khoo KH, Inoue R, et al. Characterization of oligosaccharide ligands expressed on SW1116 cells recognized by mannanbinding protein. A highly fucosylated polylactosamine type Nglycan. J Biol Chem 2005; 280: 10897-913.

[25] Nakagawa H, Kawamura Y, Kato K, Shimada I, Arata Y, Takahashi N. Identification of neutral and sialyl $\mathrm{N}$-linked oligosaccharide structures from human serum glycoproteins using three kinds of high-performance liquid chromatography. Anal Biochem 1995; 226: $130-8$.

[26] Takahashi N, Nakagawa H, Fujikawa K, Kawamura Y, Tomiya N. Three-dimensional elution mapping of pyridylaminated N-linked neutral and sialyl oligosaccharides. Anal Biochem 1995; 226: 13946.

[27] Yagi H, Takahashi N, Yamaguchi Y, et al. Development of structural analysis of sulfated $\mathrm{N}$-glycans by multidimensional high performance liquid chromatography mapping methods. Glycobiology 2005; 15: 1051-60.

[28] Yamamoto S, Hase S, Fukuda S, Sano O, Ikenaka T. Structures of the sugar chains of interferon-gamma produced by human myelomonocyte cell line HBL-38. J Biochem 1989; 105: 547-55.

[29] Takahashi N, Kato K. GALAXY (Glycoanalysis by the three axes of MS and chromatography): a web appilcation that assists structure analyses of N-glycans. Trends Glycosci Glycotechnol 2003; 15: 235-51. 
[30] Varki A. Glycan-based interactions involving vertebrate sialic acidrecognizing proteins. Nature 2007; 446: 1023-9.

[31] Suzuki Y, Ito T, Suzuki T, et al. Sialic acid species as a determinant of the host range of influenza A viruses. J Virol 2000; 74 : 11825-31.

[32] Abdel-Ghafar AN, Chotpitayasunondh T, Gao Z, et al. Update on avian influenza A (H5N1) virus infection in humans. N Engl J Med 2008; 358: 261-73.
[33] Gu J, Xie Z, Gao Z, et al. H5N1 infection of the respiratory tract and beyond: a molecular pathology study. Lancet 2007; 370: 1137 45 .

[34] de Jong MD, Bach VC, Phan TQ, et al. Fatal avian influenza A (H5N1) in a child presenting with diarrhea followed by coma. N Engl J Med 2005; 352: 686-91.

Received: March 23, 2009

(C) Thongratsakul et al.; Licensee Bentham Open.

This is an open access article licensed under the terms of the Creative Commons Attribution Non-Commercial License (http://creativecommons.org/licenses/by-nc/3.0/) which permits unrestricted, non-commercial use, distribution and reproduction in any medium, provided the work is properly cited. 